\title{
Innovation In The Early College Model: Hartford Magnet Trinity College Academy
}

\author{
Stefanie Chambers, Trinity College, Connecticut, USA
}

\begin{abstract}
In June 2011 Trinity College in Hartford, Connecticut entered a partnership with the Hartford Public Schools to launch an innovative early college model of public education. The new Hartford Middle Magnet Trinity College Academy (HMTCA) represents an expansion of the Hartford Middle Magnet School (HMMS) from a 6-8th grade school, into a 6-12th grade academy. Although Trinity has had multiple connections with the middle school, the new high school provides the college an opportunity to help prepare students for college success at Trinity and other institutions of higher learning. The partnership also allows the college to fulfill its commitment to urban engagement at the local level. Finally, it is an opportunity for the college to recruit high-achieving Hartford public school students who might select other colleges. In this paper the early college model designed by Trinity and the Hartford Public schools is presented. A proposal for the best method to measure the successfulness of the partnership is also developed. This innovative evaluation method can be applied beyond HMTCA and applied to other early college high schools across the nation.
\end{abstract}

Keywords: Early College Model; Early College High School; Measuring Educational Success; Hartford Magnet Trinity College Academy

\section{INTRODUCTION}

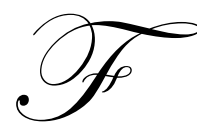

or the last twelve years a new trend in urban education reform has emerged: the early college high school. These new schools, primarily located in urban areas, attempt to help underprivileged students prepare for college and earn college credits during their high school years. These schools are also noteworthy because they involve a formal partnership between the high school and a local college. Previously limited to the country's more affluent students, these new high schools serve a very different constituency. Since their emergence in 2002, there are now approximately 250 high schools using this model. Although there is wide variation in terms of arrangements between high school and college partners, the model has become popular in many communities. Some high schools allow students to take courses at community colleges, some have agreements with four year colleges, some offer dual enrollment (students receive high school and college credit at the same time), others favor courses that count exclusively for college credit. Community College and large university partners are the most common early college structures. Less common is the model developed between Trinity College, a private and highly selective liberal arts college, and Hartford Middle Magnet School (HMMS).

In this paper I provide an overview of early college model schools, explain the origins of the Trinity College - Hartford Magnet Middle School partnership, place the Trinity - HMMS partnership in the context of similar partnerships in Hartford, and make recommendations about how best to evaluate the success of these partnerships. Because these arrangements represent a new form of urban school reform, researchers have yet to develop a method for evaluation.

\section{HISTORY AND OVERVIEW OF EARLY COLLEGE PARTNERSHIPS}

The Early College High School Initiative emerged in 2002 and created an influential education reform aimed at helping underprivileged high school students earn high school and college level credits during high school. Many of the students involved in this new reform were first generation college students living in urban areas. In 
addition to increasing the educational and economic opportunities available to urban students, the potential college savings from transfer credits amounts to significant savings for lower and moderate-income families (ECHSI 2011).

The Early College High School Initiative and several other foundations share the position that one way of leveling the urban education playing field in by creating earlier opportunities for disadvantaged students to excel academically in small schools with low student to teacher ratios, and by enrolling in college level courses. To date, they have played a role in creating or redesigning more than 270 schools, allowing over 20,000 students per year in 28 states the opportunity to prepare for higher education (Woodrow Wilson 2011 a). The Woodrow Wilson Foundation, The Gates Foundation and The Early College High School Initiative have all played a pivotal role in supporting early college model high school programs. During the early years these programs were funded in large part by the Bill and Melinda Gates Foundation (Woodrow Wilson 2011 b).

\section{HARTFORD MAGNET TRINITY COLLEGE ACADEMY}

In 1995, in the site of a formerly abandoned bus depot, a group of community leaders embarked on a mission to transform the site into a campus of city schools. Trinity College, The Institute for Living and Hartford Hospital pooled their resources to create "The Learning Corridor," as it would be named, which includes a number of public schools. The purpose of The Learning Corridor was to provide high quality schools for the children of Hartford, but also to make the surrounding neighborhood safer and more vibrant. Today, these schools compete for students from around the region due to their reputation as superior academic institutions.

Hartford Magnet Middle School was one of the schools created on The Learning Corridor Campus in 2000. Until 2011, the school enrolled a total of 600 students in grades 6-8 who were selected by lottery. The school falls under the state's 1996 landmark desegregation order, Sheff $v$. O'Neil and is required to admit $50 \%$ of the students from the City of Hartford, and 50\% from 32 surrounding suburbs. Although the school is officially part of the Hartford Public School district, it also receives support from the state due to its magnet status.

In 2010 Trinity College learned that the Hartford Schools were committed to building a small academic magnet high school of 400 students with a focus on science, the humanities, and the arts. The city reached out to Trinity and asked that the college partner with HMMS to create an Early College Model high school - the Hartford Magnet Trinity College Academy (HMTCA). One of the concerns raised by HMMS parents, school leaders and the district itself was the fact that many students who attended and excelled at HMMS for their middle school years did not have viable high school options. In an effort to build upon the success and accomplishments of the middle school students, the district proposed the early college partnership with Trinity and the expansion of the school into a 6-12 academy. As luck would have it, the school was named the best magnet school in the United States in 2011 by the D.C. based Magnet Schools of America due to their stellar academic achievement. The national award sweetened the pending partnership. From the perspective of those at the college, the initial work on the Learning Corridor, Trinity's urban focus, and the interest in recruiting more high-achieving Hartford students to Trinity, all made the endeavor a winning proposition.

HMTCA will grow one grade at a time so that by the 2014-15 school year it will have grades 6-12.. Trinity is a key player in curricular design at the high school level. The college is also works with the school to run summer bridge programs in writing and science for rising $9^{\text {th }}$ and $10^{\text {th }}$ grade students. Another key component of the partnership is that qualified HMTCA students will be able to take college level courses for credit at Trinity during their senior year. The college also plays a key role on the school's governance council. SGC's are required in all Hartford Public Schools and play a key role in school budgeting and decision-making.

\section{HARTFORD EARLY COLLEGE PARTNERSHIPS}

The national move toward early college partnerships did not miss Hartford. As of 2011 the city has several early college high schools. Each of the early college high schools is either run by CREC (Capitol Region Education Council) or HPS (Hartford Public School). During the fall of 2011 a Trinity faculty / student team evaluated nine of the city's early college high schools to better understand the similarities and differences between the various schools. Because the city has so many different schools that fall under this model, and the fact that there has been no comprehensive analysis of how the programs compare and how "success" is operationalized, we found this 
endeavor necessary. In addition, because HMTCA is the newest of the early college model high schools in the area, the assessment was particularly useful for Trinity College and HMTCA administrators. The ability to build upon some of the best practices among the early college high schools in the area was of particular interest since the HMTCA partnership is in its infancy.

The schools examined for this project include: Hartford Magnet Trinity College Academy (HPS), Classical (HPS), Capital (HPS), University (HPS), Academy of the Arts (CREC), Academy of Aerospace and Engineering (CREC), Metropolitan (CREC), Pathways (HPS) and finally, Sports and Medical Sciences Academy (HPS). On average there are twenty-one students per class with a twelve to one student/teacher ratio. Some of Hartford's early college schools structure their curriculum around specific themes. For example, the curriculum at Academy of the Arts is designed to help students pursue higher educational studies and professional careers in the creative arts. Academy of the Arts offers classes such as: creative writing, dance, instrumental music, vocal music, theater, musical theater, technical theater, visual arts, and inter-arts study. The curriculum at Academy of Aerospace and Engineering is also theme-based. Students learn and gain experience in science, technology, engineering, and math through industry partnerships (CREC 2011).

One of the innovative aspects of these early college high schools is that they prepare students for college by providing them with more than just academic instruction. In addition to meetings with guidance counselors, college fairs, and SAT classes, Hartford's early college high schools have unique programs that help send more students off to college then the regular district high schools. For example, Classical High School creates a sense of pride by providing each senior with laminated $17 \times 24$ inch posters for them to send to their former schools to showcase where they have been accepted to college. Classical also incentivizes seniors to apply to at least one four-year college by offering to pay for their bus fare to Virginia Beach for a senior trip. Principal Tim Sullivan, of Classical, explained that friends pressure each other to submit an application so that everyone can take advantage of the free bus ride for the trip. Sports and Medical Sciences Academy has a "Job Shadow" graduation requirement in which each senior must spend thirty hours with a company and document their experience. Juniors and seniors at Pathways have a "Power Block" instructional period. This period gives students an opportunity to work on their college applications and essays during the school day instead of at home. Hartford Magnet Trinity College Academy has a 30-hour summer bridge program in writing (for rising $9^{\text {th }}$ graders) and science (for rising $10^{\text {th }}$ graders) held at Trinity College that students must pass to move to the next grade level. The school has also created several mentoring programs so the high school students have a college student who can provide guidance as the students move toward the college application process.

\section{MEASURING SUCCESS: TOWARD A NEW MODEL}

Critics question whether there is too much pressure on early college high schools to report high percentages of graduates accepted to two and four-year colleges. Quantitative data suggests that early college high schools are more successful than regular district schools in sending graduates off four-year colleges. However, these data may be misleading. During interviews conducted as part of this study on early college high schools, some respondents noted a strong push among some early college high schools to "eliminate" students who do not intend to attend college. Because the schools in Hartford are magnet schools, students may leave an early college school and continue their education in a traditional district school. Moreover, one school system respondent who insisted on anonymity, reports that acceptance to college is the only indicator many of these schools use to measure their success. The number of students who actually accept the offer to attend college is a different method of measurement, and one this respondent insists is lower than reported by some early college high schools in Hartford.

This issue raises serious concerns about the way early college high schools are evaluated. If the weakest students are eliminated from the school, the school is not improving educational opportunities for students. Similarly, a model where acceptance to college, and not attendance at college, is measured is misleading. A more reliable indicator of success could be developed whereby students who enter the school and graduate are considered against those who begin and exit the program. These data are virtually impossible to track given the reluctance of schools and districts to track these trends.

An even stronger alternative measure of student success would be the number of students who attend an early college model high school, remain there, and successfully complete a four-year college program. The 
Woodrow Wilson Foundation has preliminary evidence that even with the success of the early college high school students, there is a disappointing trend emerging where graduates are not completing four-year degrees. This could have something to do with the contrast between the nurturing environment of the early college high schools and the individualistic nature of many college campuses.

Early college partnerships do not have to measure success by the number of graduates who enroll in fouryear colleges. Sometimes quality is more important than quantity. Schools can also measure success by the quality of education that they provide to prepare and motivate their students to enroll in four-year colleges after graduation. Success can be measured by the confidence and level of preparedness that students feel after participating in the unique college prep programs that early college high schools offer. Another potential evaluative tool is parental engagement. It is likely that Hartford's magnet schools already draw from an engaged pool of parents. Assessing a school based on how they work collaboratively with parents to prepare students for college would be useful. There is a literature on the importance of parental involvement in education for the outcomes of students (Henderson 2007; Lawrence-Lightfoot 2004). The HMTCA partners consider this a key factor in building a strong program. For this reason, parent education nights on high school success and the college process are offered in a tailored fashion to each cohort of parents. Another important component associated with operationalizing success is the ability of the college and high school partner to work collaboratively. During interviews, respondents associated with the various schools discussed the advantages and challenges of building an early college partnership. Because administrators and teachers at the various educational institutions have different skills and training, conversations about how to prepare students for college can present challenges. Expectations of the various partners can also change over time, so it is important to consider the strength of the relationship in a new model of assessment.

\section{CONCLUSION}

The HMTCA partnership is off to a successful start. The findings in this paper offer some useful information on the future of the partnership. The best means of building on the success of early college high schools in Hartford, and nationally, will be an important consideration in the years to come. Creating a model for measuring the success of the HMTCA partnership based on student attendance, graduation, and college attendance is also an important consideration. Aside from these easy to quantify measures, this research indicates that parental engagement and college-high school partner collaboration are key indicators of success and long-term sustainability of a successful early college model high school.

\section{AUTHOR INFORMATION}

Stefanie Chambers is associate professor of political science at Trinity College in Hartford. Her research and teaching interests include urban education policy, urban politics, and racial and ethnic politics. She is the author of Mayors and Schools: Minority Voices and Democratic Tensions in Urban Education (Temple University Press 2006). She earned her M.A. and Ph.D. in political science from The Ohio State University. Dr. Chambers is also actively engaged in educational issues in the Hartford community. She is Faculty Director of the Magnet School Partnership at Trinity College and serves on the Board of Achieve Hartford!, a local education fund. E-mail: stefanie.chambers@trincoll.edu.

\section{REFERENCES}

1. CREC. 2011. Web. 12 Dec. 2011. http://www.crecschools.org/our-schools/.

2. ECHSI. 2011. Early College High School Initiative. Web. 14 Oct. 2011. http://www.earlycolleges.org.

3. Henderson, Anne and Don Davies, Vivian Johnson, Karen Mapp. 2007. Beyond the bake sale: the essential guide to family-school partnerships. New York: New Press.

4. Lawrence-Lightfoot, Sara. 2004. The Essential Conversation: What Parents and Teachers Can Learn from Each Other. Ballantine Books.

5. $\quad$ Woodrow Wilson 2011 a. "The Woodrow Wilson Early College High School Initiative." The Woodrow Wilson National Fellowship Foundation. Web. 14 Oct. 2011. http://www.woodrow.org/.

6. $\quad$ Woodrow Wilson 2011b. "The Woodrow Wilson National Fellowship Foundation." The Bill \& Melinda Gates Foundation. Web. 14 Oct. 2011. http://www.gatesfoundation.org. 